Article

\title{
An Application of Sustainable Development in Indigenous People's Revival: The History of an Indigenous Tribe's Struggle in Taiwan
}

\author{
Cheng-Yu Yu \\ Department of Urban Planning and Development Management, Chinese Culture University, \\ Taipei 11114, Taiwan; yzy9@ulive.pccu.edu.tw; Tel.: +866-2-2861-0511 (ext. 41105)
}

Received: 2 August 2018; Accepted: 10 September 2018; Published: 12 September 2018

\begin{abstract}
Community development is seen as a crucial factor to realize sustainable development and vice versa, and for indigenous peoples in particular due to their associations with nature and natural resources. However, historical exploitation of indigenous peoples has resulted in their underachievement worldwide. The popularization of the concept of sustainable development followed a series of international treaties and conventions that shed light on indigenous peoples' revival. Drawing upon Michel Foucault's notion of the power-knowledge relationship, this article uses a case study of an indigenous tribe, the Smangus in Taiwan, to demonstrate how a politically, socially and economically disadvantaged community incorporates their traditional norms and customs into the notion of sustainable development and reinterprets it to adapt the community's conditions. By re-uniting the community and establishing a cooperative organization, the community has revived cohesion in their community. The community's conduct is investigated through the United Nations' Sustainable Development Goals 2015-2030, and the article illustrates how it fulfils three Targets and the extent to which they are fulfilled. To conclude, Smangus' case remind us of the importance of achieving sustainable development goals on micro- and local levels, and the value of empowering local communities to pursue their own sustainable development goals according to their circumstances. This article ends with suggestions for future research, and suggests that more studies using such a bottom-up approach to sustainable development would help to accumulate knowledge and experiences to establish a pattern of success to help other disadvantaged communities, draw focus to the need to bridge the policy gaps between the United Nations and local communities, and recall attention to the role of micro- and local communities to achieve sustainable development goals.
\end{abstract}

Keywords: sustainable development; sustainable development goals; community development; indigenous people

\section{Introduction}

Community development has always been an important issue and has been discussed from various angles, such as local development [1,2] and poverty reduction [3,4], and there have been various approaches to community development $[5,6]$. Many studies have linked it with sustainability and sustainable development, due to the fact that the goal of community development is to ensure that a community develops continuously in social, economic, and environmental dimensions $[7,8]$. This is particularly true when indigenous peoples are considered. The majority of indigenous peoples in the world live in remote areas which often have fragile ecosystems and rich biodiversity, and they use their traditional knowledge and rituals to guard their territories, as well as nature and natural resources $[9,10]$. However, due to rapid global population growth and the consequent expansion of human settlement, indigenous peoples' traditional territories have been gradually threatened by 
mainstream societies [11]. Moreover, the rich natural resources and need for food have accelerated the conflicts between the two sides. The typical result has been that indigenous peoples were conquered and forced to integrate into mainstream societies, and consequently lost their lands, social structures, rituals, cultures, traditional knowledge, and subjectivity [12-14]. In such a process, lands and natural resources which used to be managed by indigenous peoples began to degrade due to unsustainable exploitation. This was the case until, beginning in the 1960s, through the indigenous movement and the human rights movement, indigenous peoples' status and rights were recognized in the 1990s and finally protected in the Declaration on the Rights of Indigenous Peoples adopted by the General Assembly of the United Nations in 2007 [15].

In parallel, since the late 19th century, environmentalists began to treasure natural beauty and designated areas as protected areas and/or national parks [16]. However, the concept of protected areas was based on the "wilderness imagination" where human beings were absent [13]. As mentioned above, indigenous peoples' traditional territories often covered areas with rich environmental values and were designed as protected areas, regardless of the fact that indigenous peoples were living in them [17]. The situation changed with the emergence of the aforementioned human rights movement that fueled the indigenous movement, but the real breakthrough was the Rio Declaration on Environment and Development that not only revealed the notion of sustainable development, but also shed light on indigenous peoples [18]. The statement that "sustainable development is development that meets the needs of the present without compromising the ability of future generations to meet their own needs" revealed in the Our Common Future statement emphasized the importance of environmental consideration in development and pointed out the critical condition of the global environment [19]. More profoundly, the traditional knowledge and techniques of indigenous people were recognized as beneficial to sustainable development. For example, CBD Article 8 and 18 and Agenda 21 Article 26.4 all emphasize the values of such traditional wisdom and a willingness to cooperate with indigenous peoples to conserve nature and natural resources in order to achieve the goals of sustainable development in protected areas [20,21]. In addition, the Declaration on the Rights of Indigenous Peoples adopted by the United Nations later was another instrument to address indigenous peoples' circumstances worldwide and ensure that indigenous peoples are able to enjoy their rights "under universal norms and best practices" [22].

Since Our Common Future and the Rio Summit, sustainable development has been interpreted in various ways in accordance with individual circumstances, but the main challenge is to apply the concept to practice $[23,24]$. To tackle this issue, the Rio +20 summit in 2012 issued a set of Sustainable Development Goals (SDGs) [25], following by the SDGs 2015-2030 established in 2016 that contain 17 SDGs and 169 targets indicating the trajectory to realize the concept of sustainable development [26-28]. However, both sustainable development and SDGs are criticized as top-down approaches to address these issues, which in reality neglect the heterogeneity of individual conditions [29]. Many have called for allowing the people to speak in order to meet specific local conditions to achieve the goals of sustainable development [30]. That is to say, in their traditional territories, sustainable development will not be achieved without indigenous peoples' contributions. Thus, the extent to which indigenous peoples are able to contribute to the realization of sustainable development goals is the focus of this article. In order to better understand how such a bottom-up approach is able to reinforce the deficiencies and rigidity of top-down approaches, this article takes an indigenous tribe, the Smangus of Taiwan, as a case study to conduct the research.

Smangus is an indigenous tribe located in the remote mountainous regions of Hsinchu County, as shown in Figure 1, and its residents belong to the Atayal tribe, which is the largest indigenous tribe in Taiwan in both population and distributive areas. The altitude of Smangus is about $1500 \mathrm{~m}$, and its distance to the nearest train station is about $70 \mathrm{Km}$ which requires about $2.5 \mathrm{~h}$ drive. Situated in the mountainside of the Hsuehshan Mountain Range, Smangus is surrounding by primitive forests with rich biodiversity. The official records of the settlement could be traced back to 1913. During the Japanese Colonial Period (1895-1945), Smangus residents were forced to relocate and live supervised by the 
Japanese officials. After the colonial period, tribal people moved back to Smangus and re-established their community. Although transport was inconvenient, it was meaningful for the tribal people to go back to their original home. However, relying on wild harvesting to survive, lives were too difficult to bear, so that many residents moved to cities to settle down. In 1991, only 9 households remained in Smangus. It wasn't until the tribal people found a group of old junipers-the oldest ones were about 2500 years old - that scholars and tourists were attracted to visit, and roads to Smangus were finally constructed in 1995. Due to its underdevelopment, the tribe retains lots of indigenous traditions that also attract tourists' attention. Seeing the tourism business opportunity, many tribal people began to move back to the community from cities. Thus, roads, returning residents, scholars and tourists opened the community to the mainstream societies [31].

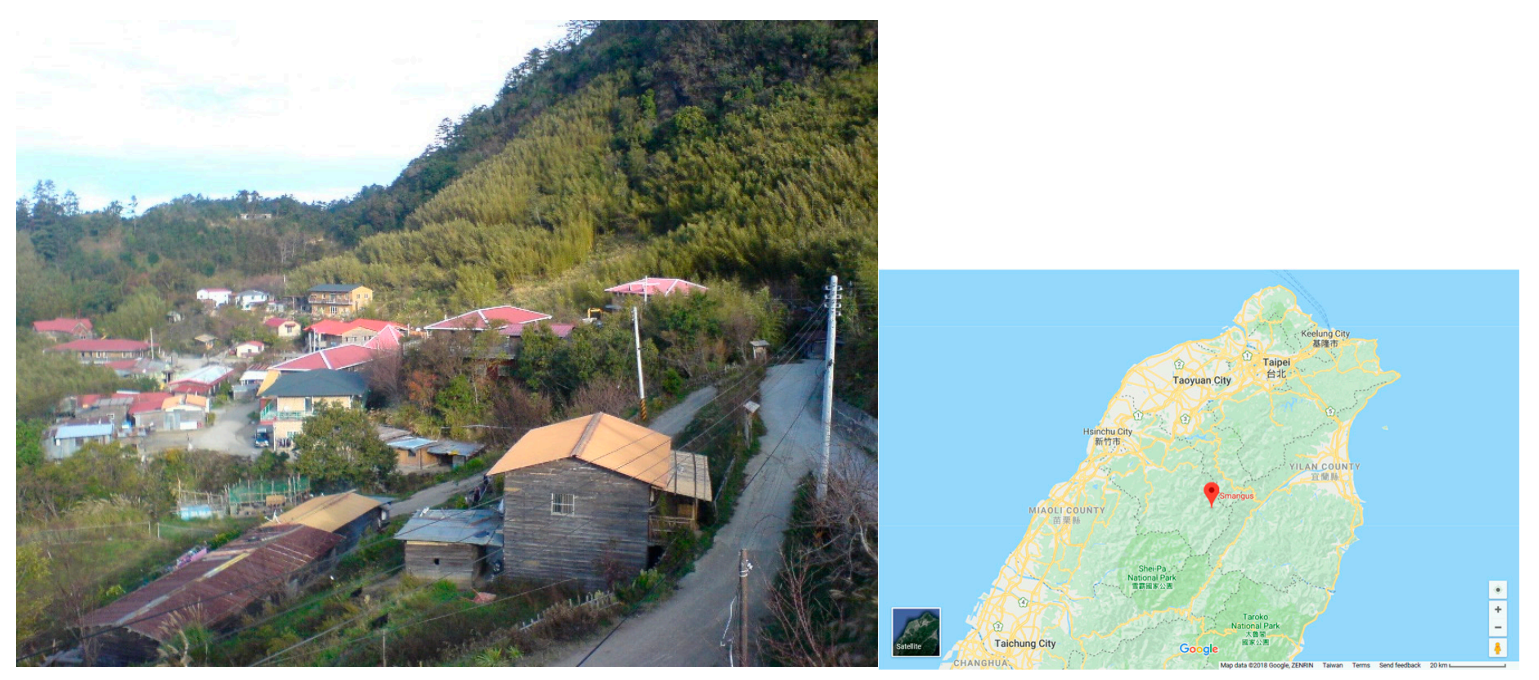

Figure 1. (Left) Smangus community. Taken by the researcher; (Right) Location of Smangus. Map Data Source: Google, ZENRIN, 2018. Access Date: 16 February 2018.

Due to the junipers, primitive environment and indigenous culture, the number of tourists visiting Smangus rose sharply [32]. Therefore, people in the community were competing with one another to attract tourists to stay in their bed-and-breakfast-type accommodation. As a consequence, the community was almost torn apart. At that time, the traditional tribal leader, Mr. Icyeh, called for unity, and after a series of discussions and influences, a cooperation system namely, the Tnunan, was established in 2004, where participants share everything from daily workload to income, and from land and properties to crops and livestock $[31,33,34]$. There were two significant factors contributing to the unity: one was the Christian faith, the other was the ability to accumulate and master experiences and knowledge. Firstly, almost all residents were of the Christian faith, so the pastors of the Presbyterian Church in Taiwan (one of them was a Smangus resident) acted as the mediator and/or coordinator to help residents communicate and negotiate. For example, when the cooperative system was first proposed, there was a member of the Presbyterian Church in Taiwan who organized a trip to take Smangus residents to visit a kibbutz in Israel. The kibbutz's model of collective community strengthened the Smangus residents' faith in the cooperative system and resulted in the later establishment of the Tnunan. Secondly, since the discovery of the junipers, various scholars have visited the community and brought new ideas. Some introduced the concept of the cooperative management system [33,35]; others helped establish international connections with American, Canadian, and Australian indigenous peoples and scholars to share their experience in managing their territories and reclaim their rights in their traditional territories [36,37]; and some helped to systematically record community history and make tribal maps of species in the ecosystems in the surrounding areas that later became a rich source of materials for their eco-tourism businesses [38,39]. These interactions not only opened the eyes of the Smangus community, but also engaged them with 
a whole new field of knowledge. To better comprehend new knowledge and communicate with outsiders, the Smangus community sent young members to study in universities-one of them obtained a master degree [31]. Such conduct afforded the community the ability and capability not only to accept and adapt to new forms of knowledge, but also to exercise it. For instance, the concept of sustainable development was introduced by scholars and young members of their community, and later this concept was re-interpreted in all documents in relation to Smangus. Moreover, Smangus people claimed that all their conduct not only obeyed their traditional norms and customs, but also matched the concept of sustainable development and fulfilled SDGs. The ability to speak a common language with outsiders, such as scholars, foreigners and mainstream societies, afforded Smangus people greater opportunities to receive assistance and benefits to revive their community. All of these developments contributed to the operation of the Tnunan and cohesion within the community. Thus, the Tnunan was finally agreed upon between the participants, and after observing their achievements, more and more residents joined the system in the following years.

The Tnunan is hierarchical, as shown in Figure 2. At the top are the tribal council, the church, and the cooperation organization, and nine departments in charge of the divergent functions of the community. Such a structure clearly presented the powerful status of traditional social norms and religious faith in the community, and eventually the community was united and organized. Unlike the traditional tribal meeting in which decisions were discussed and made between the leader and seniors, the Tnunan offered opportunities for members to have their say. Moreover, the traditional tribal structure was simple, but the Tnunan has divisions in charge of different functions in the organization.

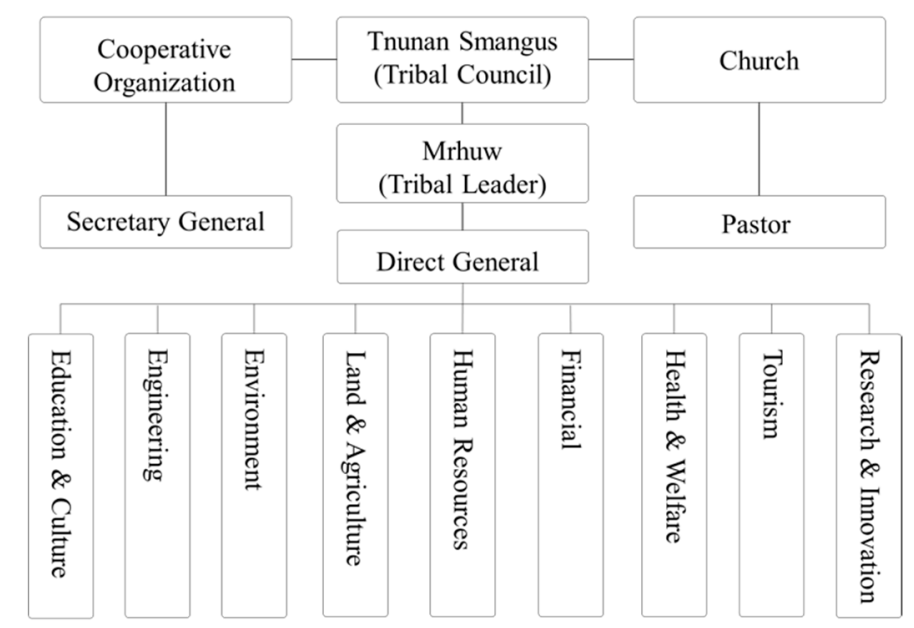

Figure 2. Tnunan, Source: [40], translated and modified by the researcher.

It can be seen that Smangus has gone through a period of struggle in which the tribal people strived for survival, for better lives to compete against other tribal people, and re-united under the cooperative system of the Tnunan. This struggle represents a transformation that changes traditional political and social structures within the community, but the result is a more cohesive community in which the vision and goals of the tribe's future are consistent amongst the members of Tnunan. In terms of economic development, nowadays the Smangus people make their livings through eco-tourism and bed-and-breakfast instead of wild harvesting. The living standards have caught up with mainstream society. Environmentally, Smangus people claim that they act in accordance with their traditional norms, that is, in an environmentally friendly manner. In sum, Smangus people claim that their community is moving towards sustainable development [31,40]. Since the primary aim of this article is to understand the extent to which indigenous peoples are able to rationalize sustainable development goals, four research questions are raised as follow:

1. How do Smangus people interpret the notion of sustainable development? 
2. How do Smangus people implement their notion of sustainable development to revive their community?

3. What has been achieved in Smangus in accordance with sustainable development?

4. What can Smangus' bottom-up approach to sustainable development contribute to the top-down approaches provided by the United Nations?

The article is therefore organized as follows. Section 2 presents the methodology in this research, including the conceptual and theoretical backgrounds, the case study, detailed data collection and analysis procedure, and a brief in research ethics. Section 3 demonstrates how Smangus people interpret and integrate the notion of sustainable development with their traditional norms and customs, such as "Gaga", and the accomplishments in relation to Sustainable Development Goals to revive their community. Section 4 concludes and provides suggestions for future research.

\section{Method}

\subsection{Conceptual and Theoretical Backgrounds}

This article employs Michel Foucault's concept of the power-knowledge relation to address the four questions raised in this research. Foucault articulates the relationship between power and knowledge by demonstrating how power and knowledge invent, constitute and reinforce one another constantly and simultaneously in a double and circular process [41-43]. In the context of governance, power is required to dispose of things, and to dispose of things in the right manner requires not only power, but also political rationality to justify one's actions [44]. Such a political rationality therefore leads the governor to a specific reality in which each of the things is convenient to be governed. That is to say, if the governor wishes to govern, one must find "space" in its rationality for the governed to "exist" in the territory under its government [45]. In such a circular process, power generates new forms of knowledge, and such a knowledge reinforces the rationality of power. At the end, a world that is both knowable and governable is structured through this power-knowledge relation [46].

Foucault's power-knowledge relation enables this article to overcome two difficulties in shaping the argument. Firstly, indigenous peoples as a whole is seen as a political disadvantaged group [13,17,47]. The assumption that Smangus people could interpret the notion of sustainable development is not based on the freedom of speech, but the governor's wishes to govern them so that one must provide space for them to exist by allowing them to speak. Moreover, in order to incorporate this new space created by Smangus people into one's territory of governance, the governor must somehow adapt to Smangus people's interpretation to a certain degree to satisfy them. This is because, for Foucault, the power relation between two objects presents an "agonism", i.e., "a relationship which is at the same time reciprocal incitation and struggle", in which domination and resistance are constantly coexisting and battling against one the other [48]. Such an agonism relationship entitles Smangus people to take a bottom-up approach in the context of sustainable development.

Secondly, applying the power-knowledge relation to the context of sustainable development, "sustainable development" is seen as an entity-a product of knowledge. In order to dispose of it in the right manner, Smangus people have to constantly exercise their power to invent, constitute and reinforce such knowledge and, in return, reinforce the power. In this process, as Foucault argues, "wisdom" is the key, that is, "knowledge of things, of the objectives that can and should be attained, and the disposition of things required to reach them" [43]. This argument lays the foundation for Smangus people to construct their knowledge of sustainable development, since their traditional knowledge encompasses everything in the locality and surrounding areas, from weather, landscape, natural resources and the usages of flora and fauna for food and medical purposes to the social and economic conditions of their own community. Thus, a precondition of this research has been established in which Smangus people are able to interpret the notion of sustainable development and implement it to accomplish their goals to revive their community. A series of data collection and 
analysis procedures are therefore implemented to comprehend how Smangus people achieve their goals in order to answer the aforementioned four research questions.

\subsection{Data Collection and Analysis}

To understand the questions addressed in this research, the case study was employed for four reasons. First, Foucault pointed out the need to focus on places where what is said and done meet and interconnect [49]. Since the research focused on the Smangus community, the case study helped to draw a clear boundary of the investigation [50,51]. Second, as Yin claims, "case study allows an investigation to retain the holistic and meaningful characteristics of real-life event" [52,53]. Third, the case study provides flexibility in choosing methods of data collection and analysis that enables the research to "address broader range of historical, attitudinal and observational issues, and to articulate perceived realities from various sources" [54]. Fourth, previous studies in relation to indigenous peoples have often employed the case study to conduct research [9].

Having justified the use of the case study in this research, qualitative methods were chosen to generate data by implementing two parallel routes, and divided data collection into three stages. First, intensive on-site observation and part-time participation in community events were carried out from 2004 to 2007, which was the beginning stage of the Tnunan. Issues and incidents in relation to rights to traditional territories were generated and occurred during this period [55-57], which tested the stability of the Tnunan and the tribal hierarchy in the community. Second, a series of in-depth interviews were conducted between 2007 and 2008. Third, visits to the community were conducted when required and when critical issues occurred after 2010. In addition, to strengthen and reconfirm the data collected on-site, a range of governmental officials and experts were interviewed and revisited and further interviewed. The procedure is shown in Figure 3.

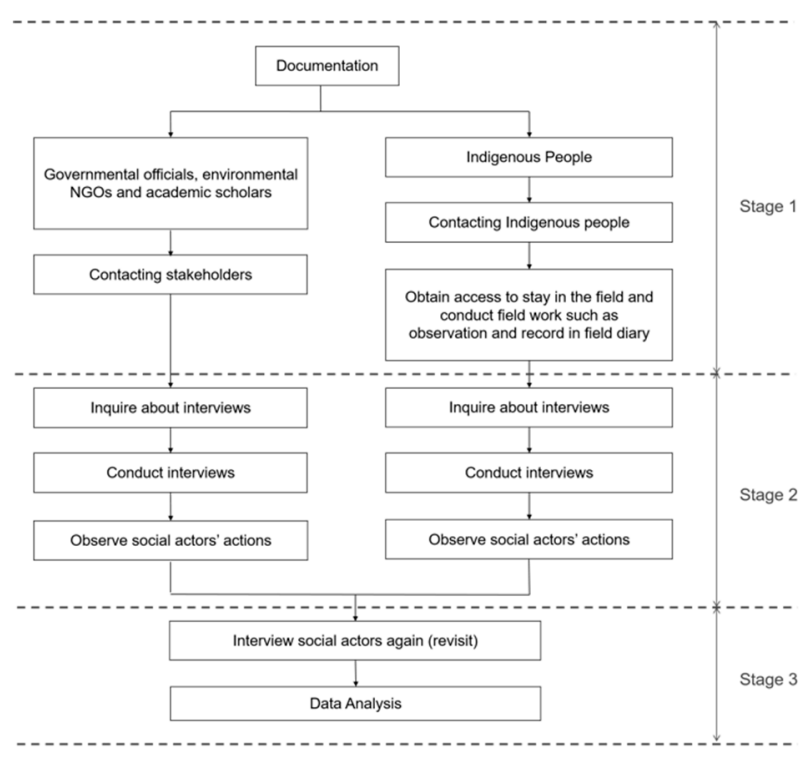

Figure 3. Data collection procedure.

In the first stage, the on-site observation and part-time participation in the community events, the researcher paid specific attention to how the Smangus community practiced their everyday lives. In doing so, the extent to which what residents did was in line with what they claimed to be sustainable was examined to conquer the value-action gap, that is, if what people said and did was different [58]. Moreover, the researcher's part-time participation in community events offered opportunities to deepen the understanding of the relationships between the community's traditional knowledge, meanings of tribal norms and taboos, and their practices. In addition, such an experience also contributed to the indigenous interviewees' willingness to talk and express views in the in-depth interviews. 
In parallel to indigenous peoples, the researcher contacted various stakeholders, including governmental officials, environmental non-governmental organizations (NGOs), and scholars who were concerned with issues related to community development and sustainable development in mountainous regions. The interviewees were identified partly from the literature review, in which key persons and organizations were frequently mentioned, and partly from several conferences in relation to indigenous peoples and national parks. The contacting tasks were relatively straightforward, most interviewees welcomed new members participating in the field of environmental protection and indigenous peoples.

In the second stage, the researchers sent the interviewees the informed consent documents and lists of questions before conducting the interviews. In total, five governmental officials across different tiers (Govt. 1-5), five academic scholars (Sch. 1-5), three leaders or members from different NGOs (NGO 1-3), and three members of the Smangus community, including a tribal leader, a senior, and a youth (S. 1-3), were interviewed. The semi-structured leading questions used for interviewing are listed in Table 1 as follow according to interviewees' status.

Table 1. The Semi-structured Leading questions for interviewing, organized by the researcher.

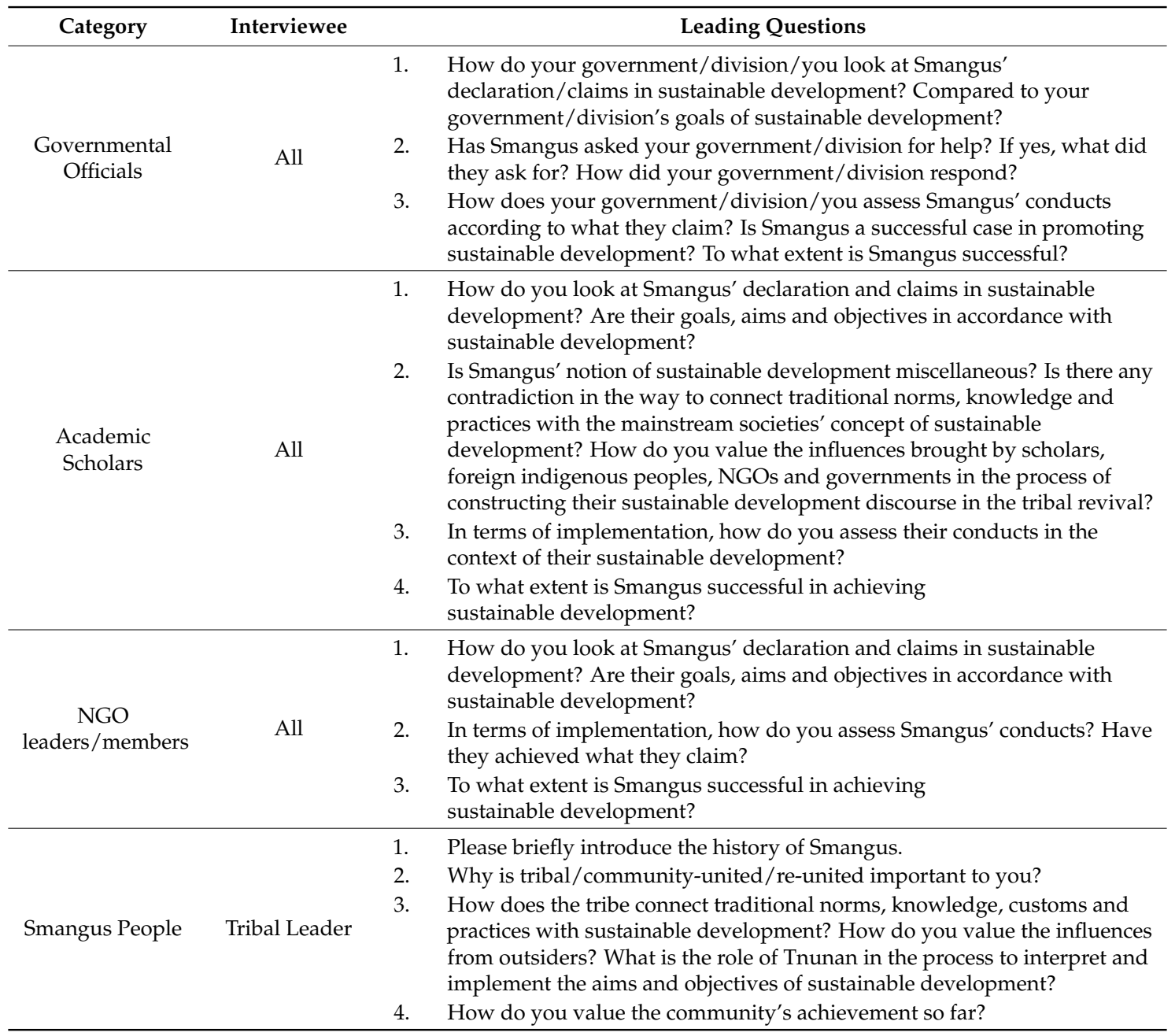


Table 1. Cont.

\begin{tabular}{|c|c|c|c|}
\hline \multirow[t]{8}{*}{ Category } & \multirow[t]{2}{*}{ Interviewee } & \multicolumn{2}{|r|}{ Leading Questions } \\
\hline & & 1. & $\begin{array}{l}\text { What does the Tribal Council mean to the tribe today? Does it still retain } \\
\text { restrictive force upon members? How does the Tribal Council } \\
\text { work nowadays? }\end{array}$ \\
\hline & Senior Member & 2. & $\begin{array}{l}\text { How does the tribe connect traditional norms, knowledge, customs and } \\
\text { practices with sustainable development? How do you value the influences } \\
\text { from outsiders? What is the role of Tnunan in the process to interpret and } \\
\text { implement the aims and objectives of sustainable development? }\end{array}$ \\
\hline & & 3. & How do you value the community's achievement so far? \\
\hline & \multirow{4}{*}{ Young Member } & 1. & What does the tribe mean to you? \\
\hline & & 2. & Whilst many young people move to cities, why do you stay in the tribe? \\
\hline & & 3. & $\begin{array}{l}\text { How does the tribe connect traditional norms, knowledge, customs and } \\
\text { practices with sustainable development? How do you value the influences } \\
\text { from outsiders? What is the role of Tnunan in the process to interpret and } \\
\text { implement the aims and objectives of sustainable development? }\end{array}$ \\
\hline & & 4. & $\begin{array}{l}\text { How do you value the community's achievement so far? Is current } \\
\text { interpretation of sustainable development leading towards a better } \\
\text { tomorrow for the community? And, for you? }\end{array}$ \\
\hline
\end{tabular}

In the third stage, the researcher continued to trace issues in relation to the Smangus community and visited the community where necessary and appropriate. Moreover, due to participation in various conferences, the researcher kept contact with the governmental officials, environmental NGOs and academic scholars. On various formal and informal occasions, the researcher had opportunities to exchange views and opinions about the affairs of Smangus, as shown in Table 2 below. The researcher recorded or noted the key points of the dialogues, which provided an alternative source of viewpoints for this research.

Table 2. The Viewpoint Exchange Notes, organized by the researcher.

\begin{tabular}{|c|c|c|}
\hline Major Incidents & Interviewee & Questions \\
\hline $\begin{array}{l}\text { Smangus Involved in Illegal } \\
\text { Logging in } 2012 \text { and } 2015\end{array}$ & S. 2, Sch. 2, & $\begin{array}{l}\text { 1. What do you know about the incidents? } \\
\text { 2. What are your views on the illegal logging incidents? } \\
\text { 3. How do you value Smangus' responses to the incidents? }\end{array}$ \\
\hline $\begin{array}{l}\text { Smangus Announced to Halve } \\
\text { Number of Tourist } \\
\text { Received in } 2015\end{array}$ & $\begin{array}{l}\text { S. 1, Sch. 3, Sch. 4, } \\
\text { NGO 2, Govt. } 5\end{array}$ & $\begin{array}{l}\text { 1. What do you know about the announcement, including } \\
\text { the background information? } \\
\text { 2. What are your views on the decision? } \\
\text { 3. How do you value Smangus' decision, particularly in } \\
\text { the context of sustainable development? }\end{array}$ \\
\hline $\begin{array}{l}\text { Government-funded/leaded } \\
\text { Developments }\end{array}$ & S. 3, Sch. 5, Govt. 2 & $\begin{array}{l}\text { 1. What do you know about the governmental projects, } \\
\text { including the background information? } \\
\text { 2. What are your views on these projects? } \\
\text { 3. How do you value these projects, particularly in the } \\
\text { context of Smangus' sustainable development? }\end{array}$ \\
\hline
\end{tabular}

In terms of data analysis, the interview transcripts were analyzed through the "Framework", that is, a method developed by the National Centre for Social Research in the U.K. [59,60]. The qualitative data obtained in this research were analyzed and interpreted through its five stages: familiarization, identifying a thematic framework, indexing, charting, and mapping and interpretation. The detailed procedure is as follows. First, to be familiar with the data, the researcher listened to the interview recordings and transcribed them into written form. In the process, the researcher also noted key ideas and recurrent themes. Second, the researcher made notes and recorded responses to research questions, jotted down recurrent themes and important issues to interviewees in order to identify a thematic framework. Such a thematic framework helped the researcher to sift and sort data, which resulted in classifying issues according to their sources and the degree of essentiality and significance to the research. As a consequence, three major types of issues/themes were identified: priority issues that were directly linked to the research questions; issues that emerged from interviewees' responses; 
and analytic themes that arose from "recurrence or patterning of particular views or experiences" [59]. As a consequence, the themes identified are, referencing the UN's SDGs 2015-2030: to sustainably manage forests and halt biodiversity loss in order to reserve nature, culture and economic opportunities; to promote the community's economic development in order to eradicate poverty; and to build an effective and accountable institution for the community in order to have a just, peaceful and inclusive society [61]. Third, the researcher subsequently transformed the identified themes into index categories to label and annotate the original text for the thematic frameworks in the indexing stage. In this stage, the researcher "inferred and decided on meaning, both as it stood and in the context of the interview as a whole, and recorded the appropriate indexing reference" [59]. Fourth, the researcher lifted the data "from their original context and rearranged them according to the appropriate thematic reference" [59]. The researcher then adopted a thematic approach and created charts which were "drawn up for each key subject area, and entries made for several respondents on each chart" [59]. The passages contained in the charts were studied and abstractly presented, with references to the original context. Thus, data was ready for mapping and interpretation. In the final stage, what the researcher did was answer the research questions through a process of "reviewing the charts and research notes; comparing and contrasting the perceptions, accounts, or experiences; searching for patterns and connections and seeking explanations for these internally within the data" [59].

In terms of research ethics, this research was conducted in an ethical manner. The introduction to tribal people was straightforward, informed consent was given before interviews, and interviewees' personal information was protected and anonymized in the article. Moreover, voice recordings were permitted beforehand and confirmed again before interviews began.

\section{Results and Discussion}

\subsection{Interpretation and Integration of Sustainable Development}

According to the tribal people, Smangus people use natural resources in an environmentally friendly manner and is an approach to sustain their traditional knowledge by constantly practicing traditional ways of life in a contemporary context. "Gaga", in the Smangus people's term (also in the Atayal tribe's term, but each community has slightly different contents comparing with others), comprises norms, rituals, knowledge, and penalties, as Sch. 1 describes: "it represented the way how Smangus People live".

Gaga regulates our behaviors and constructs our daily lives. It is an accumulation of our history and historical experiences. For example, Gaga tells us that hunting and gathering foods cannot exceed when we actually need, otherwise it is a waste of food. Foods are there in the forests, if we do not over-exploit it, the forests will always provide foods to feed us. Gaga also tells us to share what we have with others so that the tribe will unite and we will be strong. We therefore work together, eat together, share experiences in living in the forests and knowledge about flora and fauna when we gather together. We teach our young generation together, take them with us to go hunting and gathering foods in our traditional territory so that we can make demonstrations about how to trace animals and set up traps, what grass and flowers are edible etc. Before the mainstream societies' intervention, this is how we used to live here, and we try to replicate it. Of course, the mindset (S. 1).

It can be seen that Gaga, the traditional thought, presents a direct relationships between tribal people, people and the nature, and their affiliation with lands. Such a thought is similar to the contemporary conservationism thought of a balance between human and nature as well as development and environmental protection [62-65], which provides a common ground for Smangus people to communicate with scholars later. Moreover, the production and reproduction of knowledge, that is, Gaga, are constantly practiced through their daily lives, which encompasses the way they pass their experiences and knowledge about the forests and their attitudes towards the environment on to future generations. Scholars' and tourists' interests in junipers, road construction and other 
infrastructure opened the tribe to mainstream societies, which not only transformed the community from a self-sufficient community to an interdependent one, but also forced the community to adapt to mainstream societies' legislations and regulations that affected Smangus' traditional way of life. In other words, some principles of Gaga are in conflict with contemporary legislation, regulations, business models, and livelihoods. For example, indigenous peoples' traditional territories were agreed between tribes, but nowadays most of the lands belongs to the state and various tiers of governments. As a consequence, when tourism business interests induced indigenous people to conduct activities across the traditional boundaries between each tribe [66], due to a lack of constraint from contemporary legislation on such activities, the effectiveness of traditional norms in "Gaga" declined rapidly.

Last month there was a group of tourists intruded our traditional territory, and they were guided by an indigenous tour guide living in another side of the mountain. You know ... in the old days, such a conduct was forbidden because it might be seen as a provocative action and could result in a battle between two tribes. But nowadays they claimed that these lands were belong to the state, and everyone had the right to enter. By law, we had no right to disallow them to enter these lands, but by Gaga, we had the authority over the lands (S. 1).

As long as the group of tourists completed the application to visit the area, unless they did something illegal, we had no problem with that. Indigenous peoples' traditional territories are what they claim, but not being recognized by the government. Our conducts are in line with relative legislations and regulations, not their traditional whatsoever (Govt. 5).

The loss of the authority over their lands in traditional territory resulted in difficulties for Smangus peoples to practice their norms, cultural rituals, and so on. To confront such difficulties, Smangus people took a proactive approach to engage with the world. In the process of contact with mainstream societies, Smangus people received contemporary legislation, regulations, social norms, and knowledge that were different from their Gaga. With the influences from the church pastors and academic scholars, as well as other indigenous peoples in the world, the tribal people gradually engaged with the mainstream societies of Taiwan and the world.

The impact of the finding of junipers on the tribe was that an influx of tourists visiting the tribe every weekends, and tribal people began to take the opportunities to earn money. As you know, we had suffered a period of internal competition for tourists and that was terrible for the tribe as a whole. With the helps from the church pastors and some scholars, we made a huge effort to re-unite the tribe under the Tnunan. The experience taught us the danger of external values that were destructive to our Gaga and might split our tribe. However, we have already engaged with the mainstream societies, and there is no turning back (S. 3).

In such a transformational process, knowledge exchange was prominent. Indigenous peoples' traditional knowledge, encompassing everything from flora and fauna for food and medical purposes to weather, landscape, natural resources and so on, has been proven to enrich the knowledge of mankind $[9,67,68]$. The Smangus followed a similar process, especially when scholars cooperated with the community to survey and record flora and fauna species in the mountainous regions. In such an exchange, Smangus people learnt the values of mainstream societies. To deepen such an exchange process, the Smangus sent young members to study at universities and later one of them obtained a master's degree. In doing so, with help from countless scholars, the Smangus people were able to systematically integrate traditional knowledge and contemporary knowledge and consequently update their knowledge system, which was presented in the Tnunan. Moreover, mastering new technologies enabled the Smangus people to record tribal history and environmental data and map this information in a geographical context, which also enriched the contents of their eco-tourism businesses by providing guided tours for tourists $[33,69]$. Furthermore, the digitalized information enabled the Smangus community to accumulate experiences to enrich their knowledge system for future generations to inherit [31]. 
There were some members questioned about the rationale to send young generation to go to university and the Tnunan would pay for their tuition fees and living costs, which was a burden considering the fact that there was not much savings when the Tnunan was just established. The tribal leader convinced those that we had to learn how outsiders think and do, otherwise we might suffer from another difficulty in doing business and negotiating with outsiders. If happens, it might result in the collapse of Tnunan, consequently we would experience another internal competition. Finally the whole community break down and we, the Smangus community, would disappear (S. 2).

It was wised to send children to study outside the tribe. No matter what they claim, the reality is that indigenous peoples are under the sovereignty of this state and, in consequence, they have to obey laws, regulations and social norms to live the life they wish for. Offering opportunities for children to study in universities helps to mediate the misunderstandings between the mainstream society and their tribe, and we have seen some progress (Govt. 4).

It was this particular moment that brought to the researcher's attention that the notion of sustainable development was integrated into the knowledge system of the Smangus people. Although the Rio Summit was held in 1992, Taiwan finally published its Agenda 21 in 2000, and it was later updated in 2004 [70]. In other words, at the beginning of 21st century, Taiwan finally had some substantial process in sustainable development, which coincided with the development of the Smangus Tnunan, and the Smangus people noticed the opportunity and emphasized it in their documents.

In recent years, we often heard governmental officials, NGO people, scholars and almost every one emphasized "sustainable development". When we looked at the concept and principles of sustainable development, we realized that it was similar to our Gaga and Tnunan-both shared a vision to environmentally use natural resources sensibly and wisely in order to maintain biodiversity and conserve the nature; socially live safely and healthily with full social welfare; and continuously promote economic development without any harm to the environment. For example, in the old days, we relied on hunting and gathering (wild harvesting) to survive. Did we damage the environment? Not at all. We only hunted and gathered what we needs without exceeding necessity, and the biodiversity was richer than the present day. What they emphasized is what we traditionally conduct and nowadays practice (S. 2).

Based on the spirit of cooperative business, reasonably use indigenous peoples' strength in laboring works to contract construction projects in order to improve the economic conditions and quality of life, and achieve indigenous peoples' sustainable development in our lands. (Smangus Tribal Labor Cooperative, the predecessor of Tnunan). [31]

It can be seen that the Smangus people have re-interpreted the notion of sustainable development in the local context, which has not only caught up with the international and national waves of sustainable development, but also rationalized their traditional behavior. They made linkages between their traditional norms, that is, Gaga, with sustainable development, in particular, the link between their everyday practices and usage of natural resources. To compare the above statement of the interviewees of Smangus community and their documentation with the UN's Sustainable Development Goals, it is interesting to find that the Smangus' conduct matches several goals. Certainly, these goals are interconnected, but, in response to research questions, this article intends to take three goals to illustrate how Smangus people achieved these goals to revive their community. Three chosen goals are: Goal 15 Life on Land, Goal 8 Decent Work and Economic Growth, and Goal 16 Peace, Justice and Strong Institutions. 


\subsection{Sustainable Development Goals in Smangus}

\subsubsection{Goal 15 Life on Land}

Goal 15: Protect, restore and promote sustainable use of terrestrial ecosystems, sustainably manage forests, combat desertification, and halt and reverse land degradation and halt biodiversity loss [71]

Goal 15 specifically targets the conservation of forests, which is also where Smangus is located. The indicators of Goal 15 in relation to Smangus are Target 15.2, 15.4 and 15c emphasizing the sustainable management of forests, conservation of mountain ecosystems and biodiversity, and combating poaching and trafficking protected species, as well as increasing local communities' capacity to pursue a sustainable livelihood [71]. In this domain, although Smangus people largely use natural materials to construct their accommodation, they only take the falling trees and materials in the surrounding areas [72]. Moreover, for the tourists' convenience, they establish a trail to guide tourists to visit the group of junipers, and the trail is kept as primitive as possible to avoid interruption to the environment. Furthermore, when the elders pass knowledge on to the young people, they use natural materials to set traps to catch animals rather than using large animal traps or gunfire to slaughter animals. The rationale is to obey their Gaga in which Smangus people only hunted and gathered (wild harvesting) what they need without exceeding necessity, as mentioned by the Interviewee S. 2, and consequently conserve the forests.

There are, however, two illegal logging incidents happening in relation to Smangus. In April 2012, a group of criminals were arrested by policemen due to illegal logging activities. In the group, there were several criminals from the Smangus community, which caught the media's attention [73-76]. These criminals were from one family who did not participate in the Tnunan. In the incident, these criminals entered another tribe's traditional territory and conducted illegal logging activity, which is a serious offence in the Atayal's Gaga. Although these criminals were not members of the Tnunan, the tribal leader decided to visit the offended tribe and apologize in their traditional way in order to reach reconciliation between the tribes. To do so, the Smangus people visited the tribe and conducted a ritual of "blood sacrifice" under the supervision of other Atayal tribes to complete the reconciliation ceremony, and these tribes called for an end to illegal logging activities in their traditional territories [77].

It was sad that such an incident happened in our tribe, but it was also a good opportunity for us to teach our people, especially the young generation. The rationale to conduct the Sbalay ritual (blood sacrifice) is to show them, the Atayal society, and the mainstream societies that we, Atayal People, are serious about our traditions (S. 2).

The leader of Smangus certainly showed his greatness. In this incident, even though those people were belong to their tribe, but not in their Tnunan. According to the value of the mainstream societies, he has no responsibility for what they did. However, like he said, as long as he was the leader of the tribe, he had the responsibility to look after the tribal members. So that he insisted to conduct the Sbalay ritual to reach reconciliation with Pyanan tribe because he knew the seriousness of this incident in Gaga. More importantly, Smangus has become a symbol of the Atayal People in Taiwan. If Smangus did not conduct the ritual, other tribes would follow when similar incidents happened, that would eventually result in the collapse of the Gaga (Sch. 2).

The conduct in the incidents demonstrates the ways Smangus people manage their traditional territory and how traditional norms and values are integrated into their daily lives. Illegal logging, as a form of trafficking, was tackled in the incident, and the consequence of the incident in the social dimension was proactively treated by the Smangus community to show their respect to both Gaga and the offended tribe. Moreover, through such conduct, the Smangus community ensures and reclaims their rights in their traditional territory and, if other tribes conduct offensive activities 
within Smangus' traditional territory, they will have to conduct similar rituals to beg for forgiveness. Thus, as interviewee Sch. 2 commented above, the Smangus community caught this opportunity to overturn a disadvantaged incident to reach a positive outcome. In return, tourists who visit Smangus were not only interested in the junipers, but also this unique indigenous community. The result was an overwhelming numbers of tourists visited Smangus, and Smangus had to halve the number of received tourists in order to ensure the quality of reception, but also reduce the stress upon the environment, as mentioned by the interviewee in the example of the garbage waterfall incident, presented as follows $[78,79]$. See Figure 4.

The tourists were too many for them (Smangus community) to handle. There were about 30 people in the frontline dealing with 500 or more tourists, and the rest were busy preparing lunch/dinner and accommodation cleaning and hospitality. You could image the heavy workload for everyone, and certainly more and more mistakes would happen. Of course, the tourists asked/expected more than the community could offer was another issue (NGO 2).

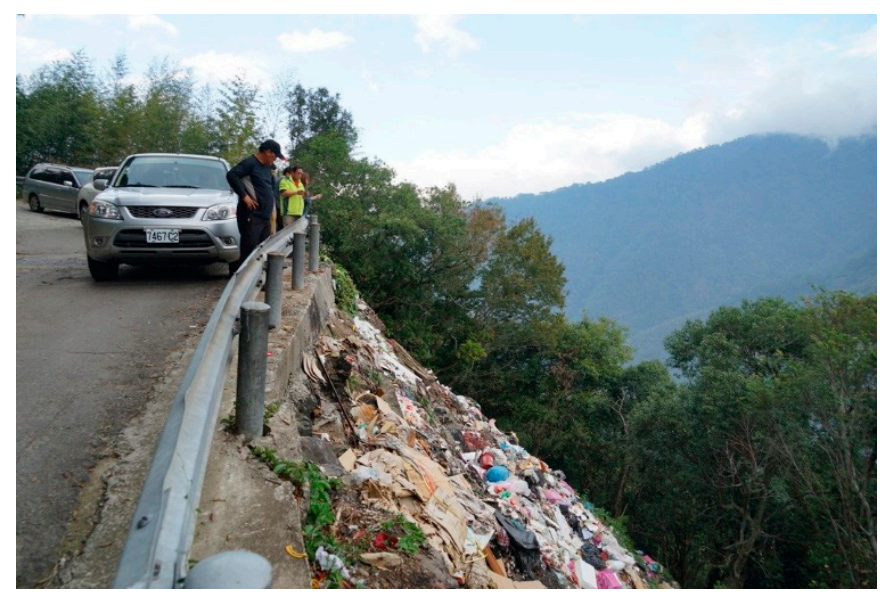

Figure 4. Garbage Waterfall, Source: United Daily News [80].

We spent four or five days helping the tribe clean the garbage waterfall. As Smangus asks tourists to take their garbage away with them, some tourists just lowered their windows and threw away the garbage at the apex of the curved road on the way back to the cities. To be honest, our citizens' public morality needs to be enhanced (Govt. 5).

The conduct to halve the number of received tourists demonstrated Smangus' concerns towards the environment, because, if they wished to earn more money, they could simply recruit more people and build more accommodation to service tourists. But they did not. Instead, they halved the number of received tourists to keep the environmental impact minimum. As the secretary of the Tnunan Council told reporters that "the community does enjoy a huge profit from eco-tourism business, but our people introspected about ourselves and our conducts, the more tourists would add pressures in water, garbage, and noise etc. that had environmentally irreversible impacts. That was the reason we have decided to halve the number of received tourists" [78]. In the balance between environmental protection and economic development, it was clear that the Smangus community chose the former. It seems that Smangus must obtain substantial financial achievement that enables them to resist the temptation of money, which leads us to the second goal, that is, Goal 8, Decent Work and Economic Growth.

\subsubsection{Goal 8 Decent Work and Economic Growth}

Goal 8. Promote sustained, inclusive and sustainable economic growth, full and productive employment and decent work for all [81]

Goal 8 tackles the economic development in general, and unemployment, labor abuse including youth and women, and specifically inequalities between gender, race, age, disability, nationalities, 
and nations. The indicators of Goal 8 in relation to Smangus are Target 8.3, 8.5 and 8.9 focusing on encouraging the growth of enterprises in all scales, providing decent work for all people across gender and age with equal pay for work of equal value, and promoting sustainable tourism to create jobs and promote local culture and products [28]. For Smangus, the finding of the group of junipers not only opened the community to mainstream societies, but also was a breakthrough in Smangus' economic development from wild harvesting to tourism business. As mentioned, the period of internal competition was a disaster for the community, but Smangus people managed to re-unite and established a micro-enterprise, that is, the Smangus Tribal Labor Cooperative (the predecessor of Tnunan), and strived for the economic profits. As mentioned in the introduction section, within the Tnunan, participants share everything from daily workload to income, and from land and properties to crops and livestock. Within Tnunan, every participant receives equal salary regardless of his/her workloads. The workloads are designated by the manager every morning according to the daily work, and individual ability and capability would be taken into account.

Every morning participants gather together in front of the public restaurant and the manager will assign works for everyone according to everyone's condition. During weekends we receive lots of tourists and the workloads are normally heavier than weekdays. Yet, during weekdays, we still have to clean the environment, inspecting the trail to the junipers, repair facilities, and organize our traditional activities in order to pass experiences and knowledge of our traditional territory on to young generations. In terms of salary, everyone receive a fixed amount of salary. The earned profits are used to subsidize participants' lives, encompassing from birth, education and wedding to illness, elder care and funeral. We live together, work together, eat together, and share everything together. This is how Smangus works (S. 2).

According to unofficial finance predictions, before halving the number of received tourists, Smangus' annual income was estimated between 20 to 40 million New Taiwanese Dollars (NTD) (around USD 0.65 to 1.3 million) [82]. For a small community, about 150 residents, with little material desire, it is a huge amount of wealth, compared with the figure that GDP per capita in Taiwan in 2017 was USD 24,318 [83]. Smangus' Tnunan has well demonstrated indicators of Goal 8 in which members of the community work together to establish a micro-enterprise to promote common wealth. Moreover, in the Tnunan, everyone's workload is similar to others and individual condition is taken into account when workload is distributed, and every participant receives the same salary and benefits from the Tnunan. Such a system illustrates the notion of equality. In addition, Smangus' business strategy in tourism is up-to-date, in which they halve the number of received tourists and turn to focus on the quality in tourist experiences, which has rewarded them with better profits [84]. Although the re-unity of the community and the establishment of the Tnunan was largely due to the great efforts of the former tribal leader, an acknowledged, stable and sustainable structure of the Tnunan is the key to success in this small community, which leads us to the third goal, that is, Goal 16, Peace, Justice and Strong Institutions.

\subsubsection{Goal 16 Peace, Justice and Strong Institution}

Goal 16: Promote peaceful and inclusive societies for sustainable development, provide access to justice for all and build effective, accountable and inclusive institutions at all levels [81]

Goal 16 calls for effective, accountable and inclusive institutions to promote safe and peaceful societies and environmental for all. The indicators of Goal 16 in relation to Smangus are Target 16.6 and 16.7, concentrating on developing effective, accountable and transparent institutions, and ensure accountable decision-making at all levels [28]. For Smangus, the Tnunan not only incorporates the tribe's traditional political and social structure, but also contemporary organizational structure in business (Figure 2). Moreover, participating in the system is voluntary, and every participant has the right to withdraw. Due to its success, more than $75 \%$ residents have participated in the Tnunan [85]. Unlike traditional tribal meetings, in which discussion and decision-making was exercised between 
the tribal leader and seniors, every participant has the right to express his/her own view in the Tnunan. Due to its small population, the Tnunan is a somewhat direct democracy, that is, everyone participates and represents himself/herself.

The Tnunan is a cooperative organization on a voluntary basis, which means participant has the right to join in and withdraw. Every participant has equal right in the Tnunan, and everything is decided through meetings where all participants are welcome to participate in and have their say. As you might know, most residents in Smangus are relatives (S. 3).

A system like the Tnunan which comprises the spirit of direct democracy has limitations and is only suitable for "a small-scale geographic community" [86]. Fortunately, Smangus is qualified, and the traditional social bond between residents of the Smangus community helps to consolidate the Tnunan. The Targets 16.6 and 16.7 are accomplished. Having said that, the rest of the Targets of Goal 16 and the recent reports present a tendency to focus on safety and security, jurisdictional equality and just, prevention of corruption and bribery etc. in national and international levels. The proposed target, that is, "to build effective, accountable and inclusive institutions at all levels" is somehow missing at the community level $[27,81,87]$. In this domain, Smangus provides a good example demonstrating how a community-level institution guarantees safety, security, equality, responsiveness, accountability, and so on. in a community, whilst it ensures environmental protection and economic development.

\section{Conclusions, Limitations and Suggestions}

\subsection{Conclusions}

This case study presents an indigenous tribe's struggle to overcome the difficulties in a rapidly changing socioeconomic environment. In this struggle, by adopting new forms of knowledge from outsiders, the Smangus community cleverly incorporates their traditional norms and customs, that is, Gaga, into the notion of sustainable development, and reinterprets it to adapt to the community's conditions. Moreover, the accumulated knowledge not only enriches their knowledge system, but also provides the Smangus community opportunities to continue the exchange of knowledge with scholars and other interest groups, which becomes a circular process to reinforce the community's power-knowledge relationship, in which the more knowledge they accumulate, the more power they obtain. Furthermore, the exchanged and accumulated knowledge adds values to their eco-tourism business by providing guided tours for tourists. Yet, more importantly, the community integrates all of these and presents them in the establishment and operation of the Tnunan-a cooperative organization which demonstrates how the Smangus community achieves sustainable development goals.

In response to the first research question, Smangus people took the opportunity to integrate their Gaga into the notion of sustainable development, by comparing their traditional knowledge and daily practice with the perspectives of sustainable development in which socioeconomic development and environmental protection are equally important and complementary $[88,89]$. To the second question, participants of the Tnunan follow the norms and customs of the Gaga as well as decisions made in the Tnunan meetings to safeguard and be accountable for their traditional territory, and develop tourism business at the same time. Moreover, the Tnunan continues to invest in their community by providing participant benefits and welfare from birth to death, education in particular. Nowadays, the Tnunan's annual income is more than 20 million NTD, which lays the foundation to continue offering participants social welfare. Furthermore, the success of the Tnunan ensures that Smangus' traditional norms and customs can continue to be practiced in their daily lives, which secures their indigenous culture. Thus, it can be said that the Smangus community has been revived in the monetary and social perspectives. To the third question, the response to the second question and the illustration in the previous section has demonstrated how and the extent to which the Smangus community has achieved in Goal 15 Life on Land, Goal 8 Decent Work and Economic Growth, and Goal 16 Peace, Justice and Strong Institution of the UN's SDGs 2015-2030. The economic achievement, the conduct to reduce the stress on the environment, and the social cohesion in the Tnunan explain the way 
in which the Smangus community finds the balance between economic, social and environmental considerations. Moreover, also in response to the fourth question, the Smangus case highlights the importance of achieving sustainable development goals at micro- and local levels. A superior international organization like the United Nations provides uniform policies, guidelines and principles that are difficult, if not impossible, to reconcile with the different political, social, economic and environmental conditions in each country, and certainly not capable of concerning a small community like Smangus. Yet, the Smangus' case indicates that only the local people know their own environment, problems and difficulties, and to achieve sustainable development means to solve their problems and difficulties. In this context, the bottom-up approach, that is, to let local people mobilize all sorts of resources to deal with their problems and difficulties, could result in a great outcome like the Smangus community. This resonates with the comment by Kates et al., that sustainable development as "a concept, in the end, represents diverse local to global efforts to imagine and enact a positive vision of a world in which basic human needs are met without destroying or irrevocably degrading the natural system on which we all depend" [89].

\subsection{Limitations}

There are several limitations in this research as follows.

First, the use of the Framework method to analyze data requires additional care. In the process of transcribing recordings to text, the language barrier, professional languages, jargon and slang in the interviews might result in misunderstanding of the meanings of the respondents. To conquer such a difficulty, the researcher conducted all transcription tasks on his own. Moreover, in the identifying a thematic framework stage, personal preferences, values and judgement would have impacts on the result. To combat this difficulty, the researcher took an approach to review transcriptions on several occasions, for example, after interviewing respondents in the second stage and third stage respectively. Due to the fact that two stages were separated by several years, there were new themes developed when adding new transcriptions after the third stage. Furthermore, indexing is highly subjective and might lead to different interpretations of data. Here, the researcher's field diary helped to remind of the circumstances in the interviews and reduce the risk of misinterpreting the interview data.

Apart from methodological limitations, financial difficulties and time constraints made the researcher unable to stay in the Smangus tribe for a long period of time, especially in the third stage when the researcher had a full-time occupation. Fortunately, due to contemporary communication technologies, nowadays keeping in touch with interviewees and tracing information about the community has become easier than before. In addition, attending conferences and meetings in relation to issues such as indigenous peoples and environmental protection provides more opportunities to meet interviewees in person, which also contributes to the opportunities to chat with and interview respondents again.

\subsection{Suggestions}

Looking to the future, new research in SDGs is still necessary. The Smangus' case represents a possibility in which, by doing the right things at the right time, a small community can make a big difference. However, the lesson learnt from this case cannot be applied or replicated universally. Two spectacular factors promoting the establishment of the Tnunan are knowledge accumulation and strong social cohesion. However, the knowledge accumulation is a long process which requires huge efforts, and the social cohesion is difficult to reach. For example, in the past decade, there have been numerous indigenous tribes in Taiwan visiting Smangus and wanting to know the key successful factors, but most of them get stuck in the consensus building process and have difficulties in negotiating with various interests. That is to say, there is a need to study more successful cases in order to establish a pattern to help other communities like Smangus. Moreover, although this article compares Smangus' achievements with the UN's SDGs, there are linkages missing at the national and regional levels. Thus, this article makes suggestions, including the following: 
- to study more successful bottom-up cases in achieving sustainable development/sustainable development goals to accumulate experiences and knowledge in order to establish a pattern to success to help other disadvantaged communities

- to bridge the gaps between policies in the superior level of the United Nations and micro- and local level of communities

- to recall attention to micro- and local communities in their achievements in sustainable development goals

Funding: This research received no external funding.

Acknowledgments: The author would like to express their appreciation to the local community people, scholars, governmental officials, and NGOs, especially the interviewees, who supported this study. In addition, this paper is dedicated to the memory of Icyeh Sulung, the former tribal leader of Smangus, and Chi Chun-Chieh, a respected teacher of mine, for their teachings during my research. May God give them eternal rest and peace.

Conflicts of Interest: The author declares no conflicts of interest.

\section{References}

1. Keating, W.D. Neighborhood Revitalization and Community Development, in International Encyclopedia of the Social \& Behavioral Sciences, 2nd ed.; Wright, J.D., Ed.; Elsevier: Oxford, UK, 2015; pp. 450-455.

2. Roseland, M.; Spiliotopoulou, M. Sustainable Community Planning and Development, in Encyclopedia of Sustainable Technologies; Abraham, M.A., Ed.; Elsevier: Oxford, UK, 2017; pp. 53-61.

3. Bradshaw, T.K. Theories of poverty and anti-poverty programs in community development. Community Dev. 2007, 38, 7-25. [CrossRef]

4. Sutawa, G.K. Issues on Bali Tourism Development and Community Empowerment to Support Sustainable Tourism Development. Procedia Econ. Financ. 2012, 4, 413-422. [CrossRef]

5. Florin, P.; Wandersman, A. An introduction to citizen participation, voluntary organizations, and community development: Insights for empowerment through research. Am. J. Community Psychol. 1990, 18, 41-54. [CrossRef]

6. Ledwith, M. Community Development: A Critical Approach; Policy Press: Bristol, UK, 2011.

7. Szitar, M.A. Learning about Sustainable Community Development. Procedia Soc. Behav. Sci. 2014, 116, 3462-3466. [CrossRef]

8. Kapera, I. Sustainable tourism development efforts by local governments in Poland. Sustain. Cities Soc. 2018, 40, 581-588. [CrossRef]

9. Beltrán, J. Indigenous and Traditional Peoples and Protected Areas: Principles, Guidelines and Case Studies; Beltrán, J., Phillips, A., Eds.; Best Practice Protected Area Guidelines Series; IUCN and WWF International: Gland, Switzerland; Cambridge, UK, 2000; Volume 4.

10. Furze, B.; De Lacy, T.; Birckhead, J. Culture, Conservation and Biodiversity: The Social Dimension of Linking Local Level Development and Conservation through Protected Areas; John Wiley and Sons Ltd.: Chichester, UK, 1996.

11. Kemf, E. (Ed.) Law of the Mother: Protecting Indigenous Peoples in Protected Areas; Sierra Club Books: San Francisco, CA, USA, 1993.

12. Colchester, M. Salvaging Nature: Indigenous Peoples and Protected Areas, in Social Change and Conservation: Environmental Politics and Impacts of National Parks and Protected Areas; Ghimire, K.B., Pimbert, M.P., Eds.; Earthscan Publications Limite: London, UK, 1997; pp. 97-130.

13. Ghimire, K.B.; Pimbert, M.P. (Eds.) Social Change and Conservation: Environmental Politics and Impacts of National Parks and Protected Areas; Earthscan Publications Limited: London, UK, 1997.

14. Feeney, T. The impact of a European Community Project on peasant families in Uganda. Oxfam Brief. 1993, 6, $1-7$.

15. Burger, J. The Gaia Atlas of, First Peoples, a Future for the Indigenous World; Doubleday: New York, NY, USA, 1990.

16. MacEwen, A.; MacEwen, M. National Parks: Conservation or Cosmetics? George Allen \& Unwin (Publishers) Ltd.: London, UK, 1982.

17. Burger, J. Report from the Frontier: The State of the World's Indigenous Peoples; Zed Books: London, UK, 1987.

18. United Nations. Rio Declaration on Environment and Development. In The United Nations Conference on Environment and Development (UNCED); United Nations: Rio de Janeiro, Brazil, 1992. 
19. Brundtland, G. Our Common Future: Report of the 1987 World Commission on Environment and Development; United Nations: Oslo, Norway, 1987; Volume 1, p. 59.

20. United Nations. Agenda 21; United Nations: New York, NY, USA, 1992.

21. United Nations. Convention on Biological Diversity; United Nations: New York, NY, USA, 1992.

22. ACHPR and IWGIA. United Nations Declaration on the Rights of Indigenous Peoples; Assembly, G., Ed.; United Nations: Copenhagen, Denmark, 2010.

23. Govindan, K.; Khodaverdi, R.; Jafarian, A. A fuzzy multi criteria approach for measuring sustainability performance of a supplier based on triple bottom line approach. J. Clean. Prod. 2013, 47, 345-354. [CrossRef]

24. Lyon, A.; Hunter-Jones, P.; Warnaby, G. Are we any closer to sustainable development? Listening to active stakeholder discourses of tourism development in the Waterberg Biosphere Reserve, South Africa. Tour Manag. 2017, 61, 234-247. [CrossRef]

25. Griggs, D.; Stafford-Smith, M.; Gaffney, O.; Rockström, J.; Öhman, M.C.; Shyamsundar, P.; Steffen, W.; Glaser, G. Policy: Sustainable development goals for people and planet. Nature 2013, 495, 305-307. [CrossRef] [PubMed]

26. Akinsemolu, A.A. The role of microorganisms in achieving the sustainable development goals. J. Clean. Prod. 2018, 182, 139-155. [CrossRef]

27. Department of Economic Social Affairs. The Sustainable Development Goals Report 2016; United Nations: New York, NY, USA, 2016.

28. United Nations. Transforming Our World: The UN 2030 Agenda for Sustainable Development. 2015. Available online: http:/ / www.un.org/ga/search/view_doc.asp?symbol=A/RES/70/1\&Lang=E (accessed on 27 August 2018).

29. Sachs, J.D. From millennium development goals to sustainable development goals. Lancet 2012, 379, 2206-2211. [CrossRef]

30. Kumi, E.; Arhin, A.A.; Yeboah, T. Can post-2015 sustainable development goals survive neoliberalism? A critical examination of the sustainable development-Neoliberalism nexus in developing countries. Environ. Dev. Sustain. 2014, 16, 539-554. [CrossRef]

31. Icyeh, L. Ima Nyux Kmal Kinbaqan Mnanu: Gaga ru Sngusun Qalang Smangus (Who Is Telling What the Knowledge Is about? The Construction of Smangus Subjectivity and Local Knowledge Practices). Master's Thesis, Providence University, Taichung, Taiwan, 2008.

32. Lin, J.-C. A Study of the Impact of Road Construction on the Development of Aboriginal Settlement. Master's Thesis, National Taiwan University, Taipei, Taiwan, 1999.

33. Chang, H.-M.; Chang, C.-F.; Wu, C.-L. Aboriginal tribal tourism development critical success factors-Case by Smangus in Taiwan. World Acad. Sci. Eng. Technol. 2013, 77, 1361-1367.

34. Tsai, H.-C. Research of the Cooperative System of the Village Smangus. Master's Thesis, Providence University, Taichung, Taiwan, 2005.

35. Horng, G.-J.; Zheng, C.-L. Development and Dilemma of a Local Tourism Management-A Case Study of Smangus Indigenous Settlement in Hsin-Chu Quarterly. J. Chin. For. 2001, 34, 229-239.

36. Lee, K.-C. The Study on the Promotion of Maqaw False Cypress National Park from within Civil Society in Taiwan. Master's Thesis, Providence University, Taichung, Taiwan, 2005.

37. National Teacher's Association (Ed.) A Vision of New Partnership between Indigenous Peoples and National Park; Council of Indigenous Peoples, Ministry of the Interior: Taipei, Taiwan, 2001.

38. Lin, Y.-R.; Wang, H.-H. Natural Resources Management: An Exploration of the Tayal Model. J. Taiwan Indig. Stud. Assoc. 2014, 4, 139-172.

39. Cheng, Y.-C. The Study of Using Public Participation Geographic Information System in Indigenous Mapping. Master's Thesis, National Taiwan University, Taipei, Taiwan, 2006.

40. Icyeh, L. Smangus; Shei-Pa National Park Headquarters: Miaoli County, Taiwan, 2011.

41. Foucault, M. Discipline and Punish: The Birth of the Prison; Allen Lane: London, UK, 1977.

42. Foucault, M. The History of Sexuality, Volume One: The Will to Knowledge; Allen Lane: London, UK, 1979.

43. Foucault, M. Governmentality, in the Foucault Effect: Studies in Governmentality -With Two Lectures by and an Interview with Michel Foucault; Burchell, G., Gordon, C., Miller, P., Eds.; The University of Chicago Press: Chicago, IL, USA, 1991; pp. 87-104.

44. Thompson, N. Inter-institutional relations in the governance of England's national parks: A governmentality perspective. J. Rural Stud. 2005, 21, 323-334. [CrossRef] 
45. Murdoch, J.; Ward, N. Governmentality and territoriality: The statistical manufacture of Britain's 'national farm'. Political Geogr. 1997, 16, 307-324. [CrossRef]

46. Murdoch, J. Post-Structuralist Geography; SAGE Publications Ltd.: London, UK, 2006.

47. Hsu, C.-L. (Ed.) International Conference on the Right of Indigenous Peoples; College of Law, National Taiwan University: Taipei, Taiwan, 1999.

48. Foucault, M. The Subject and Power, in Michel Foucault: Beyond Structuralism and Hermeneutics; Dreyfus, H.L., Rabinow, P., Eds.; University of Chicago Press: Chicago, IL, USA, 1983; pp. 208-226.

49. Foucault, M. Questions of Method, in The Foucault Effect: Studies in Governmentality-With Two Lectures by and an Interview with Michel Foucault; Burchell, G., Gordon, C., Miller, P., Eds.; The University of Chicago Press: Chicago, IL, USA, 1991; pp. 73-86.

50. Yin, R.K. Case Study Research: Design and Methods, 2nd ed.; Bickman, L., Rog, D.J., Eds.; Applied Social Research Methods Series; Sage Publications Inc.: London, UK, 1994.

51. Yin, R.K. Applications of Case Study Research, 2nd ed.; Bickman, L., Rog, D.J., Eds.; Applied Social Research Methods Series; Sage Publications Inc.: London, UK, 2003; Volume 34.

52. Kitchin, R.; Tate, N.J. Conducting Research in Human Geography: Theory, Methodology and Practice; Prentice Hall: Harlow, UK, 2000.

53. Sarantakos, S. Social Research, 2nd ed.; MacMillan: Basingstoke, UK, 1998.

54. Chen, J.C.-C. Differences between Decision-Makers in Organisations in Taiwan: Case Study on the Banking Industry. Ph.D. Thesis, Cardiff University, Cardiff, UK, 2002.

55. Wang, H.-H. Who Stole the Tgbil-The Practices of Local Knowledge in the Progress of Mrqwang Smangus' Thbil-Event. Master's Thesis, Providence University, Taichung, Taiwan, 2011.

56. Yang, M.-C. Different from the Situation of a Taiwan Zelkova: The Event Smagnus Intercultural Communication. Master's Thesis, Hsuan Chuang University, Hsinchu, Taiwan, 2012.

57. Chan, S.-K. The Difficulty of Realizing Indigenous Peoples' Rights to Land and Natural Resources under Existing Legal System: A Discussion Starting from the Taidong Beautiful Bay Litigation and the Smangus Case. Taiwan J. Indig. Stud. 2011, 4, 183-217.

58. Blake, J. Overcoming the 'Value-Action Gap' in Environmental Policy: Tensions between national policy and local experience. Local Environ. 1999, 4, 257-278. [CrossRef]

59. Ritchie, J.; Spencer, L. Qualitative Data Analysis for Applied Policy Research, in Analysing Qualitative Data; Bryman, A., Burgess, R.G., Eds.; Routledge: London, UK; New York, NY, USA, 1994.

60. Yu, C.-Y.; Chiang, Y.-C. Designing a Climate-Resilient Environmental Curriculum-A Transdisciplinary Challenge. Sustainability 2017, 10, 77. [CrossRef]

61. United Nations. Sustainable Development Goals. 2018. Available online: https://www.un.org/ sustainabledevelopment/ (accessed on 27 August 2018).

62. Davey, A.G. National System Planning for Protected Areas; Phillips, A., Ed.; Best Practice Protected Area Guidelines Series; IUCN: Gland, Switzerland; Cambridge, UK, 1998.

63. Hocking, M.; Stolton, S.; Dudley, N. Evaluating Effectiveness: A Framework for Assessing the Management of Protected Areas; Phillips, A., Ed.; Best Practice Protected Area Guidelines Series; IUCN: Gland, Switzerland; Cambridge, UK, 2000.

64. Phillips, A. Management Guidelines for IUCN Category V Protected Areas: Protected Landscapes/Seascapes; Phillips, A., Ed.; Best Practice Protected Area Guidelines Series; IUCN: Gland, Switzerland; Cambridge, UK, 2002.

65. Sandwith, T.; Shine, C.; Hamilton, L.; Sheppard, D. Transboundary Protected Areas for Peace and Co-Operation; Phillips, A., Ed.; Best Practice Protected Area Guidelines Series; IUCN: Gland, Switzerland; Cambridge, UK, 2001.

66. Lin, C.C.; Chang, C.Y.; Tsai, B.W.; Li, Y.T. Applying Public Participation Geographic Information System to the Study of the Traditional Territories of Indigenous Peoples: A Case of Atayal Smangus Community. J. Geogr. Sci. 2005, 41, 65-82.

67. IUCN. Benefits Beyond Boundaries: Proceedings of the Fifth IUCN World Parks Congress; IUCN: Gland, Switzerland; Cambridge, UK, 2005.

68. Borrini-Feyerabend, G.; Kothari, A.; Oviedo, G. Indigenous and Local Communities and Protected Areas: Towards Equity and Enhanced Conservation; Phillips, A., Ed.; Best Practice Portected Area Guidelines Series; IUCN: Gland, Switzerland; Cambridge, UK, 2004.

69. Lin, C.-H.; Chang, H.-M. Indigenous Tribe Tourism Development Critical Success Factors-Case by Bokiu in Taiwan. World Acad. Sci. Eng. Technol. 2013, 83, 1072-1078. 
70. Cao, C.-Q. The Promotion of Taiwan's Sustainable Development: The Status Quo. Sustain. Ind. Dev. J. 2003, $8,63-68$.

71. United Nations Publications (Ed.) The Sustainable Development Goals Report 2018; United Nations: New York, NY, USA, 2018

72. Lei, S.-M. Smangus Tribe, Living Together, Creating a Life of Mutual Love. Available online: https://www. ct.org.tw/1239659 (accessed on 27 August 2018).

73. Tsai, Z.-S.; Tsai, M.-S. Self-Styled Smangus Guardian, but Cut Giant Woods in Their Own Tribe. Available online: http:/ / news.ltn.com.tw/news/focus/paper/892688 (accessed on 27 August 2018).

74. Lu, S.-Z. Illegal Logging: Smangus Was Unable Speak of One's Bitter Suffering. Available online: https: / / www.coolloud.org.tw/node/68018 (accessed on 27 August 2018).

75. Shi-Min, L. Theft of the Smangus Giant Wood, the Police Arrest 31 Criminals. Available online: https: / / tw.appledaily.com/new / realtime/20150625/635683/ (accessed on 27 August 2018).

76. Huang, Z.-G.; Tsai, M.-S.; Huang, M.-Z.; Hong, M.-X. Sacred Trees Guardians Illegal Logging Sacred Trees: Smangus Is Shamed. Available online: http://news.ltn.com.tw/news/society/paper/575107 (accessed on 27 August 2018).

77. Jiang, Z.-X. Give a Pig to Conduct "Blood Sacrifice": Smangus and Pyanan Were Reconciled. Available online: http://news.ltn.com.tw/news/society/paper/581362 (accessed on 27 August 2018).

78. Tsai, M.-S. Smangus Protects the Environment and Decides to Halve the Number of Received Tourists. Available online: http:/ / news.ltn.com.tw/news/local/paper/887983 (accessed on 27 August 2018).

79. Zhang, X.-F. For Sustainable Development, Smangus Has Decided to Halve the Number of Tourists from the Second Half of This Year. Available online: https: / /www.thenewslens.com/article/18329 (accessed on 27 August 2018).

80. Chen, Y.-L. There Is A Garbage Waterfall in Smangus? Available online: https://udn.com/news/story/ $7324 / 2805389$ (accessed on 27 August 2018).

81. Department of Economic Social Affairs. The Sustainable Development Goals Report 2017; United Nations: New York, NY, USA, 2017.

82. Li, L. Smangus Teaches Me That "Life Should Not Only Be the Purpose of Making Money", in Alive Taiwan; Cite Publishing Limited: Taipei, Taiwan, 2015.

83. Yu, G. History of GDP per Capita in Each Country. Available online: http://www.chinatimes.com/ newspapers/20180701000373-260209 (accessed on 27 August 2018).

84. Luo, Y. Fewer Tourists but Increasing Income? Smangus Makes You Want to Go Regardless How Far It Is; Commonwealth Magazine Group: Taipei, Taiwan, 2018.

85. Zhu, T. Smangus, the Tribe of God. Available online: http://www.chinatimes.com/newspapers/ 20150513000889-260115 (accessed on 27 August 2018).

86. Johnson, R.J.; Gregory, D.; Pratt, G.; Watts, M. (Eds.) The Dictionary of Human Geography, 4th ed.; Blackwell Publishers Inc.: Oxford, UK, 2000.

87. Economic and Social Council. Progress towards the Sustainable Development Goals 2018; United Nations: New York, NY, USA, 2018.

88. Nilsen, H.R. The joint discourse 'reflexive sustainable development' - From weak towards strong sustainable development. Ecol. Econ. 2010, 69, 495-501. [CrossRef]

89. Kates, R.W.; Parris, T.M.; Leiserowitz, A.A. What is sustainable development? Goals, indicators, values, and practice. Environment 2005, 47, 8-21.

(C) 2018 by the author. Licensee MDPI, Basel, Switzerland. This article is an open access article distributed under the terms and conditions of the Creative Commons Attribution (CC BY) license (http://creativecommons.org/licenses/by/4.0/). 